\title{
Research on Optimal Investment Portfolio of Enterprise Annuity under Investment Constraints
}

\author{
Xiaozheng Cao \\ School of Management, Jinan University, Guangzhou, China \\ Email: cxz1184494800@sina.com
}

How to cite this paper: Cao, X.Z. (2018) Research on Optimal Investment Portfolio of Enterprise Annuity under Investment Constraints. American Journal of Industrial and Business Management, 8, 2391-2402. https://doi.org/10.4236/ajibm.2018.812160

Received: November 29, 2018

Accepted: December 21, 2018

Published: December 24, 2018

Copyright $\odot 2018$ by author and Scientific Research Publishing Inc. This work is licensed under the Creative Commons Attribution International License (CC BY 4.0).

http://creativecommons.org/licenses/by/4.0/

\begin{abstract}
Using Markowitz's mean-variance model, this article measured the yields and risks of the four major investment instruments under the premise of different investment portfolios in the current enterprise-annuity-investment constraints. Finally, under the existing annuity investment constraints, this paper found that 1) corporate bonds are better than government bonds from the security and profitability of the enterprise annuity portfolio, 2) the combination of two or more investment instruments can more diversify risks, 3) stock investment needs to be selected in the portfolio, the higher the proportion of stock investment, the greater the yield of the enterprise annuity portfolio.
\end{abstract}

\section{Keywords}

Enterprise Annuity, Optimal Portfolio, Investment Constraints

\section{Introduction}

According to the China Statistical Yearbook, China's aging population reached 235.86 billion by the end of 2016 , accounting for $16.7 \%$ of the country's total population. It is expected to exceed 300 million by 2025. In order to cope with the severe aging social crisis and truly realize the "old-age support", China has successively promulgated and revised the "Enterprise Annuity Trial Measures" and "Enterprise Annuity Fund Management Measures". The establishment of this system has enabled the number of enterprises and employees participating in enterprise annuities and the amount of annuity accumulated has increased significantly. As of the end of the third quarter of 2016, a total of 760,580 enterprises in China had established enterprise annuities, the number of employees participating in insurance reached 23.329 million, and the accumulated annuity 
amounted to 1066.631 billion. However, for a long time, China's huge amount of enterprise-annuity assets investment was limited to bank deposits and government bonds, resulting in extremely low investment returns, which made it unable to effectively support the government to build a multi-pillar pension system. With the attributes of public goods, enterprise annuities have more restrictions on investment choices and higher requirements on the level of risk control. On April 30th, 2015, the Ministry of Human Resources and Social Security revised and improved some regulations of the "Administrative Measures for Enterprise Annuity Funds" (referred as the "New Management Measures" hereinafter), and made further adjustments on the safety of annuities and the conditions for employees' early withdrawal to ensure greater security, profitability and liquidity. Based on the investment constraints in the "New Management Measures", the key is choosing the optimal portfolio of enterprise annuity to achieve the balance between income and risk.

There are many problems in the practice of China's basic endowment insurance fund. On the one hand, the new and old systems have large cost of integration and the supervision system is not perfect. Financing model of "partial accumulation system" cannot play a role in alleviating the pressure on pension fund payment. On the other hand, due to the restrictions imposed by investment instruments, enterprise annuity funds cannot be invested in multiple channels, which leads to serious depreciation. Enterprise annuities cannot cope with the negative impact of population aging, and huge payment pressures urgently need to be resolved. China's enterprise annuity will face a large depreciation risk from the collection to the final payment of retirees, and the enterprise annuity is special in nature, which puts higher requirements on safety and profitability. If the value of the enterprise annuity cannot be effectively realized, it will threaten the stability and security of the society. Therefore, it is of vital importance to reform the current enterprise-annuity-investment model and construct a suitable investment method to realize the preservation and appreciation of the fund. This research on the investment operation of the enterprise annuity undoubtedly has great theoretical and practical significance.

Using Markowitz's mean variance model, this paper selects the national debt index, corporate bond index, and the average annual growth rate of the Shanghai Composite Index from 1997 to 2016 to represent the yields of government bonds, corporate bonds and stocks, respectively. And one-year bank deposit interest rates were selected to represent the yields of liquidity income tools. Then, under the premise of the current enterprise-annuity-investment constraints, this paper measures the yield and risk of these four investment instruments under different investment portfolios. Finally, for the security and profitability of the enterprise annuity portfolio, this paper finds that 1) corporate bonds are better than government bonds, 2) the combination of two or more investment instruments can more diversify risks, 3) stock investment needs to be selected in the portfolio, the higher the proportion of stock investment, the greater the yield of the enterprise annuity portfolio. 
The contribution of this paper is: On the one hand, enterprise annuities can receive high returns through the investment and operation of the capital market, and its significance is not only to ease the payment pressure brought about by the aging of the population, but also to promote the development of China's financial market. This paper finds that the optimal investment portfolio under the existing investment constraints, which will help the enterprise annuity to maintain and increase its value and promote the development of the capital market.

On the other hand, how to establish a management system and investment system for the basic old-age pension system has become an important issue in development of China's pension insurance system. This paper proves the shortcomings of the existing investment policy_the constraint on stock investment affects the better value-added of enterprise annuity, which provides reference for policy makers.

The article is organized as follows: the second part is literature review, the third part is data selection and model design, the fourth part is hypothesis and empirical analysis, and the last part is conclusion.

\section{Literature Review}

Using sophisticated calculations to measure combined mean and combined variance under different portfolios, the article written by Markowitz (1952) [1] in the Journal of Finance first brought mathematical statistics into the portfolio, which has led to the revolution in the financial investment community. This method has also been rapidly applied to the study of annuities. Since the 1980s, more and more economists have begun to focus on the research of corporate annuity portfolios and risk measures.

Enterprise annuity plans are largely influenced by government policies, such as tax policies. Therefore, scholars study the investment and operation of annuities from the government's annuity system arrangement (such as pension income tax incentives and guarantees). Sharpe (1976) [2] proposes a "reinsurance arbitrage" strategy (PBGC Effect) in which all assets are invested in stocks (risk assets). He believes that there is a chance of "reinsurance arbitrage" because it only needs to provide a fixed premium to the Pension Benefits Guarantee Corporation (PBGC) without considering tax incentives.

The tax arbitrage model is considered from another perspective. It was proposed by Black (1980) [3] and Tepper (1981) [4]. If the enterprise annuity fund is not insolvent and does not take into account the use of PBGC's premium arbitrage, investors will buy more shares than bonds since the tax rate of dividend is much lower than the tax rate of bonds, especially corporate bonds, so the bonds must generate sufficient income if they want to attract more taxable investors. If the government exempts the tax on investment income of the enterprise annuity fund, then the tax-exempt investors can obtain "economic rent". The tax arbitrage model believes that pension fund legal persons should make full use of tax provisions for maximum benefit. 
Harrison and Sharpe (1982) [5] theoretically considered the tax effect and the option effect. They believe that the combination of options and tax effects can result in a corner solution for a portfolio of corporate annuity assets. If the fund is in good operating condition and the taxation level is high, then the enterprise annuity will be fully invested in the bond to get the benefits of the tax shield as much as possible. But if the fund is in a poor operating condition and is on the verge of loss, the enterprise annuity will invest in risky securities.

Brinson, et al. (1986) [6]'s research has made people aware of the importance of asset allocation. The results show that strategic asset allocation contributes a lot to portfolio investment returns, while market-timing and securities selection contribute relatively much less. Roger, et al. (1999) [7] used the monthly yields of 94 balanced funds from 1985 to 1995 and the quarterly yields of 58 pension funds from 1993 to 1997 to study the impact of asset allocations on portfolio returns and the level of this impact.

Jorge Mina (2005) [8] studied the risk management of an annuity plan and pointed out that risk budgeting is a method of constructing an annuity plan that is closely linked to the risk-return characteristics of investors. He defined the risk budget and described the risk budget process of the annuity plan and explored the technical means in risk budget management.

China's enterprise annuity development is relatively late, and theoretical research is still few. Domestic scholars' research on enterprise annuity mainly focuses on the investigation of foreign enterprise annuities and the analysis of China's annuity investment portfolio based on existing foreign theories. Cui Shaomin et al. (2003) [9] and Sun Jianyong (2003) [10] used Markowitz's mean-variance theory to study how to reduce the investment risk by optimizing the investment portfolio of the enterprise annuity, so as to manage the enterprise annuity better. In recent years, related research has increased slightly. For example, Hu Qiuming and Jing Peng (2014) [11] established the DCC-GARCH-CVaR model and found that the optimal asset structure of enterprise annuity fund has certain time-varying characteristics, and the optimal weight of asset allocation is the trade-off of asset income and risk between the various types. Wu Fucheng et al. (2015) [12] conducted research from the perspective of the board of directors. From the perspective of supervision, Zheng Qiong (2016) [13] believes that the value-added of annuity requires the relevant laws and the improvement of the internal system of the enterprise. Han Lei and Zhang Shengtai's (2017) [14] results show that under the current constraint ratio, China's enterprise annuity yield cannot reach the per capita disposable income growth rate. Therefore, companies should be encouraged to establish an annuity plan and gradually liberalize investment restrictions.

It is not difficult to find through the above literature review that using Markowitz's portfolio theory and asset allocation model to analyze the yield and risk of enterprise annuity portfolio is a research method jointly adopted by scholars at home and abroad. The foreign literature mainly uses the Western countries' 
pension and enterprise annuity data for empirical analysis. At present, there is few research on the preconditions of the new management method for the middle-aged asset investment. To determine the optimal combination of Chinese enterprise annuity investment at this stage, this paper used Markowitz's mean-variance model and combined it with the constraints of China's enterprise annuity investment in the "New Management Measures", then selected four investment tools to calculate the investment return rate and risk level of the four investment instruments under various investment ratios.

\section{Data Selection and Model Design}

\subsection{Data Selection}

China's enterprise annuity system is relatively well-developed among large-scale enterprises such as state-owned enterprises and foreign-funded enterprises. Therefore, the relevant data of the Shanghai Stock Exchange is more representative. The annual average growth rates of the government bonds index, corporate bond index and Shanghai Composite Index for 1997-2016 are selected to represent the yields of government bonds, corporate bonds and stocks respectively. The one-year bank deposit interest rate is selected as the return rate of liquidity income instruments.

Table 1 shows that from 1997 to 2016, the minimum yield of one-year bank deposits was $2.7 \%$, and its fluctuation range was also small, with a maximum of $5.67 \%$ and a minimum of $1.50 \%$. The yields of national debt and corporate bonds were middle, $3.7 \%$ and $5.44 \%$, respectively, and the fluctuation range was $-3.93 \%-16.60 \%$, and $-5.41 \%-24.09 \%$, respectively. The yield of stock is up to $14.91 \%$, and its fluctuation is also the highest, the minimum is $-65.39 \%$, and the maximum is $130.43 \%$.

\subsection{Data Analysis}

Table 2 shows that the standard deviation of one-year bank deposits (R1) is the lowest, less than $1 \%$, and the yield is also the lowest, less than $3 \%$; the standard deviation of government bonds (R2) and corporate bonds (R3) are not high, which means that these two types of investment tools are relatively safe. Among them, the expected yield of corporate bonds is slightly higher than 5\%. Compared with government bonds, corporate bonds are an ideal investment tool. The yield of stock (R4) is close to $15 \%$, it is much higher than several other investment tools, but the risk is also extremely high, reaching 45.52\%. However, the United States has the most mature capital market, its Dow Jones index is the most authoritative and representative index of the global stock market, and the standard deviation of it is less than $20 \%$ in recent decades. It can be seen that China's stock market is still immature and volatile. Therefore, from the perspective of security, it is irrational to use stocks as a single investment tool in China's enterprise annuity fund investment.

Table 3 and Table 4 show the correlation among these four investment in- 
struments. The correlation coefficient between stocks and other three types of investment instruments are all more than 0.2 , which means stocks are correlated with the other three. Specifically, stocks are positively correlated with one-year bank deposits, and have a certain negative correlation with government bonds and corporate bonds.

The correlation coefficient between one-year bank deposits and government bonds and corporate bonds are not higher than 0.15 , which means they are extremely weakly related.

The most prominent is the correlation coefficient between government bonds and corporate bonds, closing to 0.9 means they are significantly related. It is not difficult to realize the income curves of these two types of investment tools will rise and fall at the same time, making the purpose of diversifying risks cannot be achieved. Therefore, combined with the rate of return and risk, we can conclude that stock investment combined with one or more of the other three types of investment tools can reduce investment risk and guarantee higher yield, which is a safe and reasonable investment model.

Table 1. Yields of bank deposits, government bonds, corporate bonds and stocks (\%).

\begin{tabular}{|c|c|c|c|c|}
\hline Year & Bank deposits & Government bonds & Corporate bonds & Stocks \\
\hline 1997 & 5.67 & 9.18 & 12.92 & 30.22 \\
\hline 1998 & 3.78 & 4.72 & 3.91 & -3.97 \\
\hline 1999 & 2.25 & 3.02 & 0.23 & 19.18 \\
\hline 2000 & 2.25 & 3.05 & 2.32 & 51.73 \\
\hline 2001 & 2.25 & 2.60 & 10.23 & -20.62 \\
\hline 2002 & 1.98 & 2.53 & 2.9 & -17.52 \\
\hline 2003 & 1.98 & -1.27 & -2.98 & 10.27 \\
\hline 2004 & 2.25 & -3.93 & -4.13 & -15.40 \\
\hline 2005 & 2.25 & 14.07 & 24.09 & -8.33 \\
\hline 2006 & 2.52 & 2.14 & 0.77 & 130.43 \\
\hline 2007 & 4.14 & 1.22 & -5.41 & 96.66 \\
\hline 2008 & 2.25 & 16.60 & 17.02 & -65.39 \\
\hline 2009 & 2.25 & -2.14 & 0.67 & 79.98 \\
\hline 2010 & 2.75 & -1.84 & 7.42 & -14.31 \\
\hline 2011 & 3.50 & 4.05 & 3.50 & -21.68 \\
\hline 2012 & 3.00 & 3.34 & 7.49 & 3.17 \\
\hline 2013 & 3.00 & 2.75 & 4.36 & -6.75 \\
\hline 2014 & 2.75 & 4.42 & 8.73 & 52.87 \\
\hline 2015 & 1.50 & 6.08 & 8.84 & 9.41 \\
\hline 2016 & 1.75 & 3.37 & 5.93 & -11.74 \\
\hline Avg. & 2.70 & 3.70 & 5.44 & 14.91 \\
\hline
\end{tabular}

Source: China Statistical Yearbook, Shanghai Stock Exchange Statistical Yearbook and Market Information. 
Table 2. Yield and standard deviation of various tools (\%).

\begin{tabular}{ccccc}
\hline & $\begin{array}{c}\text { Bank } \\
\text { deposits }\end{array}$ & $\begin{array}{c}\text { Government } \\
\text { bonds }\end{array}$ & $\begin{array}{c}\text { Corporate } \\
\text { bonds }\end{array}$ & Stocks \\
\hline Yield & 2.70 & 3.70 & 5.44 & 14.91 \\
Sd & 0.94 & 4.86 & 6.95 & 45.52 \\
\hline
\end{tabular}

Table 3. Covariance between various types of tools.

\begin{tabular}{ccccc}
\hline & $\begin{array}{c}\text { bank } \\
\text { deposits }\end{array}$ & $\begin{array}{c}\text { government } \\
\text { bonds }\end{array}$ & $\begin{array}{c}\text { corporate } \\
\text { bonds }\end{array}$ & stocks \\
\hline Bank deposits (R1) & 0.89 & 0.61 & 0.13 & 8.51 \\
Government bonds (R2) & 0.61 & 23.61 & 28.07 & -73.69 \\
Corporate bonds (R3) & 0.13 & 28.07 & 48.35 & -137.35 \\
Stocks (R4) & 8.51 & -73.69 & -137.35 & 2072.52 \\
\hline
\end{tabular}

Table 4. Correlation coefficients between various types of tools.

\begin{tabular}{ccccc}
\hline & $\begin{array}{c}\text { Bank } \\
\text { deposits }\end{array}$ & $\begin{array}{c}\text { Government } \\
\text { bonds }\end{array}$ & $\begin{array}{c}\text { Corporate } \\
\text { bonds }\end{array}$ & Stocks \\
\hline Bank deposits & 1 & 0.13 & 0.02 & 0.20 \\
Government bonds & 0.13 & 1 & 0.83 & -0.33 \\
Corporate bonds & 0.02 & 0.83 & -0.43 & -0.43 \\
Stocks & 0.20 & -0.33 & & 1 \\
\hline
\end{tabular}

\subsection{Model Design}

Markowitz has a lot of theories and models of portfolios. The empirical analysis in this paper only uses the mean-variance model for brief analysis. The auxiliary tools are matlab software. The mean-variance model is as follows:

Objective function: $\min \sigma 2\left(R_{p}\right)=\sum \sum X_{i} X_{j} \operatorname{Cov}\left(R_{i}-R_{j}\right)$

$$
R_{p}=\sum X_{i} R_{i}
$$

where $R_{p}$ is the combined rate of return, $R_{i}$ is the yield of the $i$-th stock, $X_{i}$ and $X_{j}$ are the investment ratios of securities $i$ and $j, \sigma 2\left(R_{p}\right)$ is the combined investment variance (combined total risk), and $\operatorname{Cov}\left(R_{i}-R_{j}\right)$ is the covariance between two securities. The above formula can calculate the expected combined rate of return under the certain ratio of each investment instrument, and make sure the risk $\sigma 2\left(R_{p}\right)$ is minimized. The economic significance is that investors can predetermine a desired level of return, which can be used to determine the total investment risk of a portfolio plan under different investment ratios.

\section{Simulation Analysis of Enterprise Annuity Optimal Portfolio}

\subsection{Propose Assumption}

From the above data, we can see that the return rate and risk of stock investment 
are the highest among the four investment instruments in a single investment tool. Therefore, we propose the hypothesis H1: in the enterprise annuity portfolio, the stock investment amount accounts for the total enterprise annuity. The higher the proportion of investment, the higher the return on the portfolio and the higher the risk.

Since government bonds are the least risky investment method except bank deposits, and the rate of return is similar to that of corporate bonds, we propose hypothesis $\mathrm{H} 2$ : in the enterprise annuity portfolio, there is a substitution effect between government bonds and corporate bonds, and the choice of government bonds is better.

According to the relationship between risk and return, no matter which kind of investment tool satisfies the higher the return and the greater the risk, we assume thatH3: the enterprise annuity portfolio also follows the investment law, the higher the expected rate of return, the greater the risk of combination.

\subsection{Investment Constraint Parameter Setting}

According to the newly revised "Administrative Measures for Enterprise Annuity Funds" in 2015, 1) the proportion of liquidity products such as investment bank demand deposits shall not be less than $5 \%$ of the net value of the investment enterprise annuity fund; 2) the proportion of fixed income products, such as bank time deposits, government bonds and corporate bonds shall not exceed $95 \%$ of the net value of the investment enterprise annuity fund; 3 ) the proportion of equity products such as investment stocks shall not exceed $30 \%$ of the net value of the investment enterprise annuity fund. Combined with the mean-variance model, the investment constraint is set to $X_{1} \geqq 5 \%$, $X_{2}+X_{3} \leqq 95 \%, X_{4} \leqq 30 \%$.

\subsection{Determination and Analysis of the Optimal Portfolio}

Objective function: $\min \sigma 2\left(R_{p}\right)=\sum \sum X_{i} X_{j} \operatorname{Cov}\left(R_{i}-R_{j}\right)$

$$
\begin{aligned}
& R_{p}=\sum X_{i} R_{i} \\
& \text { limitation factor: } 1=\sum X_{i} \\
& X_{1} \geqq 5 \% \\
& X_{2}+X_{3} \leqq 95 \% \\
& X_{4} \leqq 30 \%
\end{aligned}
$$

Assume that the necessary return rate of the annuity portfolio is $8 \%$. Under the above constraints, the expected combined yield and combined covariance under various investment portfolios are obtained using matlab software, as shown in Table 5.

Table 5 shows that the higher the expected rate of return for the later portfolio, the higher the risk. Schemes $14-20$ are feasible based on the requirement of a required rate of return of $8 \%$, where scheme 14 is consistent with the minimum covariance in the mean-variance model, but scheme 20 is the best combination from the perspective of yield. For the above table, a line chart of the pro- 
portion of investment tools in each plan was made to analyze it more intuitively, as shown in Figure 1.

We can see that the farther to the right (the higher the rate of return and risk), the higher the proportion of stocks and the lower the proportion of bank demand deposits, which also reflects the extremely low yield of low risk of bank deposits. The higher the proportion of stock investment, the higher the rate of return and risk, so the assumption 1 is true.

At the same time, we can also see that under the fixed expected rate of return, the proportion of corporate bonds is basically higher than that of government bonds, and corporate bonds rise a lot. However, the government bonds is basically $0 \%$, which is related to the result that the yield of corporate bond is higher than that of government bonds in a single rate of return. That is, under the existing interest rate of China's government bonds, if there are only two investment instruments, corporate bonds and government bonds, it is the best solution for enterprise annuity investment to invest in corporate bonds. Therefore, the first half of hypothesis 2 is true and the latter part is not true. Corporate bonds have a substitution effect on government bonds, but corporate bonds are better than government bonds.

As shown in Figure 2, under the constraint of the investment ratio of each tool, the combined covariance increases with the increase of the combined rate of return, which means the investment risk increases with the increase of the expected rate of return, so the assumption 3 is true. The highest yield is close to $10 \%$ means the expected rate of return on the enterprise annuity portfolio cannot exceed $10 \%$ under the framework of the state's laws and regulations on corporate annuity.

$120.00 \%$

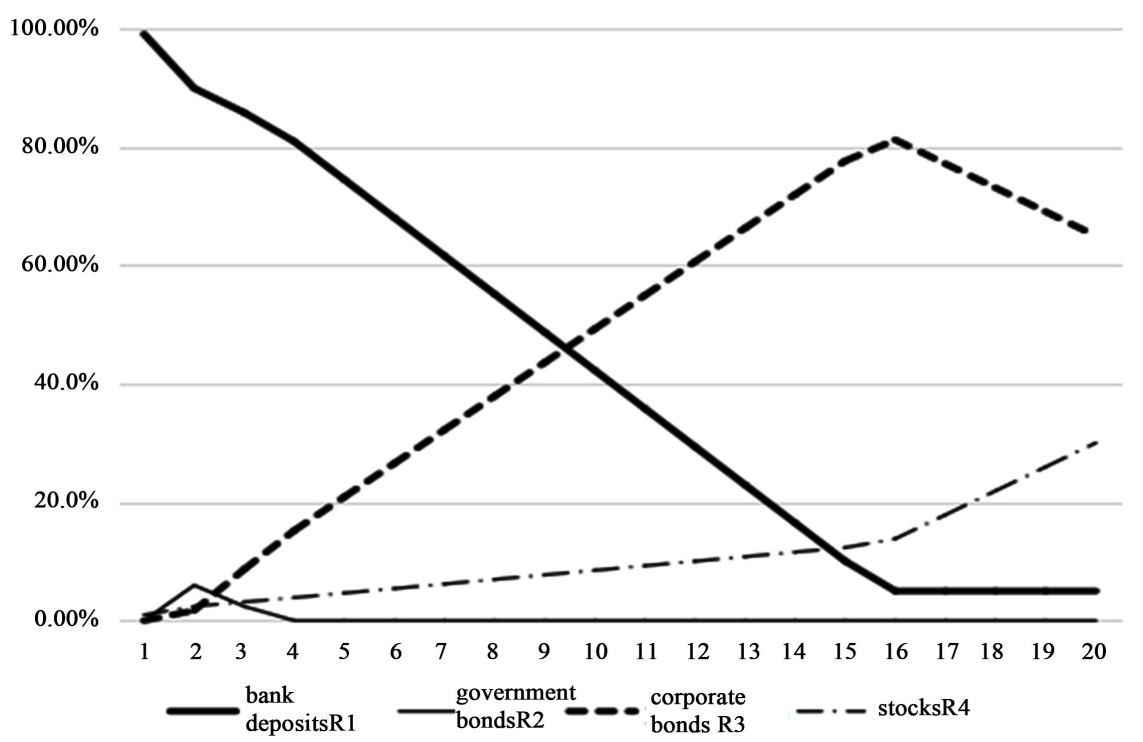

Figure 1. Proportion map of investment tools for each program. 


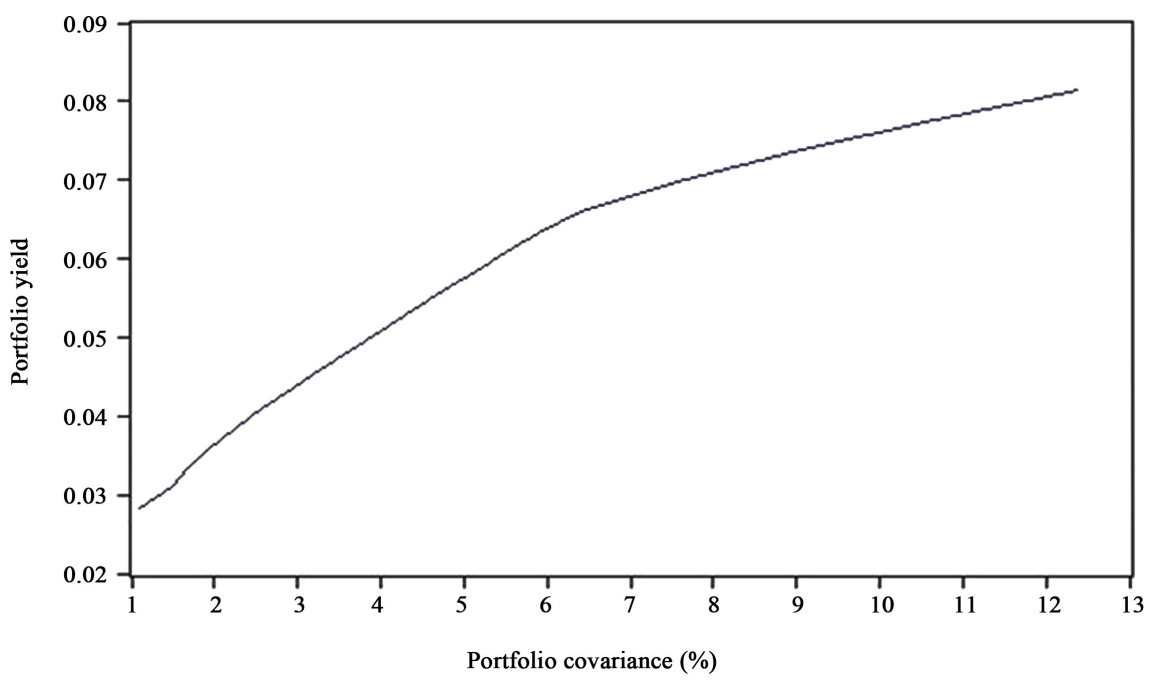

Figure 2. Combined rate of return and covariance line chart.

Table 5. Combined return rate and combined covariance under each investment ratio.

\begin{tabular}{|c|c|c|c|c|c|c|}
\hline Portfolio & $\begin{array}{c}\text { Bank } \\
\text { deposits }\end{array}$ & $\begin{array}{l}\text { Government } \\
\text { bonds }\end{array}$ & $\begin{array}{l}\text { Corporate } \\
\text { bonds }\end{array}$ & Stocks & $\begin{array}{l}\text { Portfolio } \\
\text { yield }\end{array}$ & $\begin{array}{l}\text { Portfolio } \\
\text { covariance }\end{array}$ \\
\hline 1 & $99.03 \%$ & $0.00 \%$ & $0.00 \%$ & $0.97 \%$ & $2.82 \%$ & $1.11 \%$ \\
\hline 2 & $89.89 \%$ & $5.97 \%$ & $1.71 \%$ & $2.43 \%$ & $3.10 \%$ & $1.49 \%$ \\
\hline 3 & $85.77 \%$ & $2.40 \%$ & $8.68 \%$ & $3.15 \%$ & $3.35 \%$ & $1.69 \%$ \\
\hline 4 & $80.89 \%$ & $0.00 \%$ & $15.22 \%$ & $3.88 \%$ & $3.59 \%$ & $1.94 \%$ \\
\hline 5 & $74.45 \%$ & $0.00 \%$ & $20.90 \%$ & $4.65 \%$ & $3.84 \%$ & $2.25 \%$ \\
\hline 6 & $68.01 \%$ & $0.00 \%$ & $26.57 \%$ & $5.42 \%$ & $4.09 \%$ & $2.58 \%$ \\
\hline 7 & $61.57 \%$ & $0.00 \%$ & $32.24 \%$ & $6.19 \%$ & $4.34 \%$ & $2.93 \%$ \\
\hline 8 & $55.13 \%$ & $0.00 \%$ & $37.92 \%$ & $6.96 \%$ & $4.59 \%$ & $3.28 \%$ \\
\hline 9 & $48.69 \%$ & $0.00 \%$ & $43.59 \%$ & $7.72 \%$ & $4.84 \%$ & $3.64 \%$ \\
\hline 10 & $42.25 \%$ & $0.00 \%$ & $49.26 \%$ & $8.49 \%$ & $5.09 \%$ & $4.01 \%$ \\
\hline 11 & $35.81 \%$ & $0.00 \%$ & $54.93 \%$ & $9.26 \%$ & $5.34 \%$ & $4.39 \%$ \\
\hline 12 & $29.36 \%$ & $0.00 \%$ & $60.61 \%$ & $10.03 \%$ & $5.59 \%$ & $4.76 \%$ \\
\hline 13 & $22.92 \%$ & $0.00 \%$ & $66.28 \%$ & $10.80 \%$ & $5.83 \%$ & $5.14 \%$ \\
\hline 14 & $16.48 \%$ & $0.00 \%$ & $71.95 \%$ & $11.57 \%$ & $6.08 \%$ & $5.52 \%$ \\
\hline 15 & $10.04 \%$ & $0.00 \%$ & $77.62 \%$ & $12.33 \%$ & $6.33 \%$ & $5.90 \%$ \\
\hline 16 & $5.00 \%$ & $0.00 \%$ & $81.18 \%$ & $13.82 \%$ & $6.61 \%$ & $6.40 \%$ \\
\hline 17 & $5.00 \%$ & $0.00 \%$ & $77.14 \%$ & $17.86 \%$ & $6.99 \%$ & $7.58 \%$ \\
\hline 18 & $5.00 \%$ & $0.00 \%$ & $73.09 \%$ & $21.91 \%$ & $7.38 \%$ & $9.05 \%$ \\
\hline 19 & $5.00 \%$ & $0.00 \%$ & $69.05 \%$ & $25.95 \%$ & $7.76 \%$ & $10.68 \%$ \\
\hline 20 & $5.00 \%$ & $0.00 \%$ & $65.00 \%$ & $30.00 \%$ & $8.14 \%$ & $12.41 \%$ \\
\hline
\end{tabular}




\section{Conclusions and Suggestion}

Through the above empirical analysis, we can see that the higher the proportion of stocks in the enterprise annuity portfolio, the higher the expected rate of return and the higher the risk, which may be related to the immature capital market and the volatility of stock prices in China. The role of government bonds is replaced by corporate bonds, because the existing corporate bonds have a low risk which is similar to the government bonds, and have a higher yield than the other one. This is also in line with the state's encouragement for corporate bond investment. The enterprise-annuity-investment portfolio still conforms to the basic law of investment: high risk is accompanied by high returns, which can be confirmed from the perspective of both investors and fundraisers, and we have the same results above. Therefore, the optimal investment portfolio of China's corporate annuity is not certain.

At this stage, the development of the capital market is immature. If more consideration is given to safety, the risk under the established rate of return will be minimized. As the capital market matures, the enterprise annuity investment can gradually pursue higher returns to choose the maximum benefit for a given security then. For enterprise annuities that flow within three years, liquidity investment instruments could be chosen such as bank deposits; for short-term enterprise annuities, fixed-income instruments are better such as corporate bonds; for enterprise annuities used for a long-term investment, investing in stocks with good reputation, high potential and stable stock price is a good idea.

At the same time, in the above analysis, the yield of the enterprise annuity portfolio is related to the proportion of stocks. However, due to the volatility of the stock market, considering the security, the policy constrains the proportion of stocks within $30 \%$, which is an important factor in the failure of the annuity portfolio investment rate to break through $10 \%$. If higher yield, the proportion of stocks must be increased, but this will increase the investment risk at the same time. Therefore, the excessive volatility of the stock market has become the crux of the problem. Under the current situation, considering the safety of enterprise annuity investment, the constraint of national policy on stock ratio is very reasonable, but in order to get long-term development, it is necessary to gradually improve the capital market and stabilize the stock price and make it fluctuate within a reasonable range. And then considering the profitability, the constraints on the share of stocks could be loosened gradually, making enterprise annuity investment get higher investment income under the established security so that the enterprise annuity can support the aging pressure of society more effectively.

\section{Conflicts of Interest}

The author declares no conflicts of interest regarding the publication of this paper.

\section{References}

[1] Markowitz, H.M. (1952) Portfolio Selection. The Journal of Finance, 7, 77-91. 
[2] Sharpe, W.F. (1976) Corporate Pension Funding Policy. Journal of Financial Economics, 6, 183-193. https://doi.org/10.1016/0304-405X(76)90002-7

[3] Fisher, B. (1980) The Tax Consequences of Long Run Pension Policy. Financial Analysts Journal, 36, 25-31.

[4] Irwin, T. (1981) Taxation and Corporate Pension Policy. Journal of Finance, 38, $1-13$.

[5] Michael, H.J. and Sharpe, W.F. (1982) Optimal Funding and Asset Allocation Rules for Defined Benefit Pension Plans. University of Chicago Press, Chicago, 91-103.

[6] Brinson, G.P., Hood, L.R. and Beebower, G.L. (1986) Determinants of Portfolio Performance. Financial Analysts Journal, 42, 39-44. https://doi.org/10.2469/faj.v42.n4.39

[7] Ibbotson, R.G. (2005) Does Asset Allocation Policy Explain 40\%, 90\%, or 100\% of Performance? Yale School of Management, Yale.

[8] Mina, J. (2005) Risk Budgeting for Pension Plans. Risk Metrics Group, New York City, NY.

[9] Cui, S.M., Liu, Y.S., Wang, Z.F., Hu, X.C. and Zeng, Q.W. (2003) Research on the Development of Chinese Enterprise Annuity. Economic Research Reference, 45, 2-18.

[10] Sun, J.Y. (2003) Enterprise Annuity: An Important Pillar of Social Security. Economic Daily.

[11] Hu, Q.M. and Jing, P. (2014) Research on Dynamic Optimization of Enterprise Annuity Fund Asset Structure-Based on DCC-GARCH-CVaR Model. Insurance Research, 8, 64-72.

[12] Wu, F.C., Bi, X., Liu, Y., Bi, Z. and Yang, G.M. (2015) Quantitative Research on Enterprise Annuity Investor Portfolio under the Trustee Mode of the Council. Wuhan Finance, 1, 48-50.

[13] Zheng, Q. (2016) Research on Portfolio Management of Enterprise Annuity. Times Finance, 32, 248.

[14] An, L. and Zhang, S.T. (2017) Research on Enterprise Annuity Investment Portfolio in China. Productivity Research, 2, 132-135. 